\title{
The Basic Needs of Plantation Workers: A Company View
}

\author{
George Moody-Stuart ${ }^{1}$
}

In attempting to define a 'Company view' of the basic needs of plantation workers, I begin with a brief overview of changing company attitudes towards plantations themselves.

As little as 20 years ago, most transnational companies interested in tropical agricultural production could probably have seen no sensible alternative to plantations. The more liberal would have acknowledged the political and social attractions of smallholder production, as something to be indulged in a small way but not to be too seriously encouraged because of the inevitability of disillusionment. Few indeed would have foreseen smallholders as a genuine and viable alternative within a decade or two.

Times have changed. Kenya, with its strong agricultural traditions and its relatively short colonial history, has provided prime examples of successful smallholder schemes with the Kenya Tea Development Authority and the Mumias Sugar Company, operating in two traditional plantation crops. Transnational companies now recognise that it is frequently not appropriate for them to own large tracts of land in developing countries and that providing technical and administrative assistance to smallholders may be a good alternative.

Having acknowledged the increasing significance of smallholders in 'plantation crops', however, it seems certain that plantations will continue to play an important role in developing-country agriculture for many years to come. If transnationals and other plantation owners can adapt to the existence of smallholder agriculture, to what extent can they, or have they already, changed their attitudes towards the basic needs of their workers?

Looking back even to the early post-war years, the management of a British company operating in a colonial territory (which would now be an independent developing country) would have seen its prime - even its sole - obligation as being to its shareholders. That does not mean that it would have been a bad employer by the standards of the times - frequently British companies offered considerably better terms and conditions than local employers - but merely that its

\footnotetext{
The author has worked for Booker Agriculture International Limited for 20 years, in the UK and overseas, but the views expressed are essentially his own rather than formal company policy.
}

motivation was uncomplicated: to maximise its shareholders' dividends.

Nowadays, however, it is very widely accepted that the Company has three sets of obligations:

to its shareholders

to its workforce and

to the community (or to the State)

The order is not siginificant because these sets of obligations are interdependent and inseparable. If the Company does not make a profit for its shareholders, it will soon cease to be able to employ its workforce or to pay its taxes. If the Company does not give its workforce decent terms and conditions, it is unlikely to remain efficient and competitive (e.g. by causing pollution), it will not be allowed to employ people or earn profits.

That is the theory and it is to a great extent true in practice also. However, it is only realistic to recognise that in this chain of mutual dependence, the weak link is the workforce. Except in those countries with very strong trades unions or close government/union cooperation, it is not easy for plantation labour to force improvements on unwilling management. They can, of course, strike or riot or quit, but the principal victims of such actions are usually the workers themselves. There is no doubt that the principal motivation for the Company to meet the basic needs of the workforce, unless it is compelled to do so by law, is enlightened self-interest.

It may be useful at this stage to divide basic needs, as seen by one employer, into two groups - 'very basic' and 'slightly less basic'. Very basic needs are wages, housing, medical facilities, education and adequate safety standards.

Slightly less basic needs are pensions, food and drink at the work place, social and recreational facilities, shopping facilities, transport.

Wages. From a company view, these are, of course, the most basic need of all. The typical transnational employer likes to pitch his wage rates at the upper end of the market rate for the job. It is not clever to pay substantially above the market rate, even if the Company can afford to do so. If the market rate appears to be unfairly low, it is better to spend more on amenities (and to push the wage rate up slowly) than to risk disrupting the economy and perhaps causing 
serious damage to other employers who are in a weaker position. It should go without saying that wages must be paid promptly (weekly or fortnightly in accordance with local practice) and in such a manner that the worker understands how the pay packet is made up.

Housing. Generally, the less housing the Company can provide, the better for all concerned. This is because the provision of decent housing is tremendously costly both in capital and in maintenance terms, to an extent which may even damage the viability of the Company. But perhaps more important is the fact that Company housing necessitates all sorts of intrusions by the Company into the lives of the occupants. An employer plays a large enough role in the life of a worker without telling him how many of his relatives can live in his house or what he may grow in his garden; but such restrictions are unavoidable in Company housing. The ultimate hardship arises, also, if a man who loses his job loses his house too. It is, however, often necessary to build houses to attract and retain labour. As with wages, the transnational will hope (and be expected) to be near the top end of the local standard in housing, and must provide clean water and adequate sanitation.

Medical facilities. Depending on the size of the unit, the Company may expect to provide a doctor and some medical assistants and nurses, working in one or more clinics to provide primary health care. It is usually unwise to provide a hospital. Money is better spent on an ambulance or even perhaps a light aircraft to ferry the seriously ill or injured to a government hospital. The limitations of medical facilities are a constant headache to the conscientious rural employer. He will normally accept it as his duty to provide a service to his own workers and their immediate families. But who knows whether a sick child belongs to an employee? What good doctor will refuse treatment to a seriously ill person anyway? In practice the large Company probably has to accept that it is going to provide a primary medical service to the whole area in which it operates.

Education. A simple and satisfactory division of responsibility is for the company to provide the buildings and the Government to provide the teachers. 'Buildings' may stretch to teachers' housing and, of course, it is likely that the wives of local senior staff may constitute a useful pool of teachers. This formula seems to work. In 1986 the Mumias Complex School, run on the above lines, achieved the best examination results among more than 12,000 primary schools in Kenya, probably aided by the fact that the headmaster like many of his colleagues did not have to expend his energies in ensuring that the school building did not fall about his ears.
Safety Standards. In the developing world, industrial safety is something of which the Company is generally much more conscious than the workers or the trade unions. The enforcement of safety rules is an uphill battle, but one which the responsible employer must not shirk. It is not unusual for transnationals to insist on all serious industrial accidents being reported by telex to the Head Office. This at least prevents complacency on the part of the employer.

Pensions. In the developing world, pensions seldom spread below the salaried staff level. With a fairly mobile workforce, a national rather than a Company scheme seems to be the only practical solution. Employers would generally be happy to see better arrangements. It is not pleasant to have to enforce retirement on a man with no money, particularly if he is going to lose his house at the same time.

Food and drink at the work-place. Where there is a large concentration of workers at one place, it is sensible to have a canteen, preferably run by a contractor. The Company may subsidise this by providing a building and perhaps electricity, free or at low cost. For agricultural workers, a supply of clean water at the field edge is essential. Availability of some basic foodstuff at low cost may pay dividends in higher productivity.

Social and recreational facilities. This is an area in which the struggling Company will always try to economise. Conversely, it is one in which the successful Company may most easily improve the lot of its workforce without upsetting the economic balance.

Shopping facilities. A Company may consider the provision of serviced sites to shopkeepers as an amenity to its workers. It would be unwise to become directly involved itself.

Transport. Most Companies avoid involvement, as far as possible, in workers' transport. It is mentioned here as an alternative, in some cases, to the provision of housing. Loans for the purchase of bicycles are another possibility.

In summary, it is probably the view of all responsible Companies that it is greatly in their own interest to assist the members of their workforce to achieve satisfaction of their basic needs. Sometimes the responsibility falls fairly and squarely on the Company's shoulders; but it is desirable that the Company should avoid becoming more involved than necessary in its workers' lives. Where a third party, whether Government or private enterprise, can help to provide for basic needs, the Company is wise to encourage and assist this, financially or by other means. 